\title{
Progressive headache in a 48-year-old man
}

\author{
Mohanad M Al-Obaidi, Faisal A Khasawneh
}

Texas Tech University Health Sciences Center, Amarillo, Texas, USA

\section{Correspondence to} Dr Faisal A Khasawneh, faisal.khasawneh@ttuhsc.edu

Accepted 6 December 2014

\section{DESCRIPTION}

A 48-year-old man with diabetes mellitus and alcoholic cirrhosis presented with a throbbing headache of 1-month duration. The patient did not have a history of intravenous drug use.

On physical examination, he was afebrile but disoriented with nuchal rigidity.

Head CT scan was negative. Lumbar puncture (LP), performed after the first dose of cefotaxime was given, showed a white cell count (WCC) of 84620 cells/ $\mu \mathrm{L}$ with $96 \%$ neutrophils. MRI of the brain revealed multiple ring-enhancing lesions consistent with brain abscess (figure 1).

Gram-positive cocci in pairs were seen in the cerebrospinal fluid (CSF), but blood and CSF cultures were negative. CT of the chest, abdomen and pelvis were negative for abscesses. A transthoracic echocardiogram was negative for vegetations.

The patient was started on cefotaxime and vancomycin with no improvement in his condition. A $20 \mathrm{mg}$ dose of intrathecal vancomycin was given daily for 5 days. An LP performed on the 10th day showed WCC of 720 . He completed an 8-week course of intravenous cefotaxime ( $2 \mathrm{~g}$ every $6 \mathrm{~h}$ ) with complete resolution of symptoms.

\section{DISCUSSION}

Brain abscesses manifest with a triad of headache, fever and focal neurological deficit in $20 \%$ of patients. ${ }^{1}$ Blood and CSF cultures are positive in $68 \%$ of cases with streptococci and staphylococci isolated in $34 \%$ and $18 \%$ of samples, respectively.

Brain abscess can rupture into the subarachnoid space or the ventricular system leading to meningitis or ventriculitis with mortality rates of up to $85 \%$. $^{2}$

Intravenous antibiotics for at least 8 weeks are recommended to treat brain abscesses. Ventriculitis might slow clinical response and intrathecal/intraventricular administration of antibiotics could be of help. ${ }^{3}$

\section{Learning points}

- Ventriculitis complicating brain abscess rupture is a serious condition that carries high morbidity and mortality. Early diagnosis is crucial to avoid poor outcome.

- Ventriculitis can be visualised on MRI; ependymal wall thickening and a high-intensity signal on $\mathrm{T} 2$ will be evident. Furthermore, debris may be seen in the ventricle.

- In addition to intravenous antibiotics, intrathecal antibiotic administration should be considered in ventriculitis patients with slow clinical response.
To cite: Al-Obaidi MM, Khasawneh FA. BMJ Case Rep Published online: [please include Day Month Year] doi:10.1136/bcr-2014208736

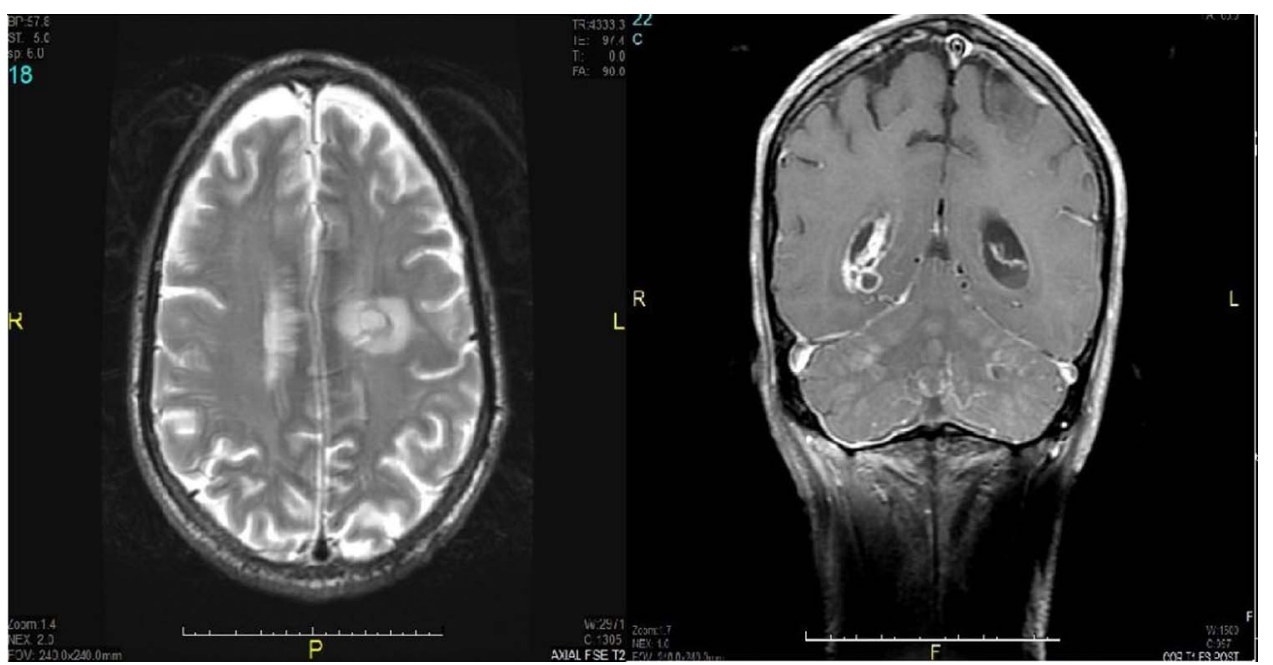

Figure 1 Left panel is an axial T2-weighted MRI of the brain showing a ring-enhancing lesion involving the left frontal-parietal lobe junction with oedema surrounding it. Right panel is a coronal T1-weighted fat-saturated postgadolinium MRI of the brain with signal enhancement of debris within the posterior horn of the left lateral ventricle, and also showing an abscess that has ruptured in that ventricle. 
Contributors MMA-O and FAK diagnosed the infection and reviewed the literature and wrote the manuscript.

Competing interests None.

Patient consent Obtained.

Provenance and peer review Not commissioned; externally peer reviewed.

\section{REFERENCES}

1 Brouwer MC, Coutinho JM, van de Beek D. Clinical characteristics and outcome of brain abscess: systematic review and meta-analysis. Neurology 2014;82:806-13.

2 Brouwer MC, Tunkel AR, McKhann GM II, et al. Brain abscess. N Eng J Med 2014:371:447-56.

3 Ziai WC, Lewin JJ III. Update in the diagnosis and management of central nervous system infections. Neurol Clin 2008;26:427-68.

Copyright 2015 BMJ Publishing Group. All rights reserved. For permission to reuse any of this content visit http://group.bmj.com/group/rights-licensing/permissions.

BMJ Case Report Fellows may re-use this article for personal use and teaching without any further permission.

Become a Fellow of BMJ Case Reports today and you can:

- Submit as many cases as you like

- Enjoy fast sympathetic peer review and rapid publication of accepted articles

- Access all the published articles

- Re-use any of the published material for personal use and teaching without further permission

For information on Institutional Fellowships contact consortiasales@bmjgroup.com

Visit casereports.bmj.com for more articles like this and to become a Fellow 